\title{
Gamijeonssibaekchulsan regulates mast cell-mediated anaphylactic reaction
}

\author{
Phil-Dong Moon ${ }^{1,2}$, Hye-Young Shin ${ }^{3}$, Ho-Jeong $\mathrm{Na}^{3}$, Hyun-Ja Jeong ${ }^{1,2}$, Su-Jin Kim ${ }^{1,2}$, \\ Jae-Young Um ${ }^{1}$, Rae-Kil Park ${ }^{4}$, Hyung-Min Kim ${ }^{1}$ and Seung-Heon Hong ${ }^{2 凶}$ \\ ${ }^{1}$ College of Oriental Medicine, Institute of Oriental Medicine, Kyung Hee University, Seoul, Republic of Korea; \\ ${ }^{2}$ College of Pharmacy, Wonkwang University, Iksan, Jeonbuk, Republic of Korea; ${ }^{3}$ College of Pharmacy, Woosuk \\ University, Wanju, Jeonbuk, Republic of Korea; ${ }^{4}$ VestibuloCochlear Research Center of Wonkwang University, \\ Iksan, Jeonbuk, Republic of Korea
}

Received: 10 January, 2007; revised: 08 May, 2007; accepted: 22 May, 2007 available on-line: 04 June, 2007

\begin{abstract}
Gamijeonssibaekchulsan (GJBS) is a typical Oriental medicine prescription which has been used in Korea for the treatment of allergic diseases and the development of physical strength. However, as yet there is no clear explanation of how GJBS affects the anaphylactic reaction and the immune function. In the present study murine models and MOLT- 4 cells, a $T$ cell line, were used to investigate these effects. Compound 48/80-induced systemic anaphylactic shock and ear swelling response were firstly analyzed. We also assayed histamine release and passive cutaneous anaphylaxis (PCA) in mice and cytokine productions in MOLT-4 cells. GJBS significantly inhibits compound 48/80-induced systemic anaphylactic shock and ear swelling response. GJBS also inhibits histamine release from rat peritoneal mast cells induced by compound 48/80. PCA activated by anti-dinitrophenyl immunoglobulin $\mathrm{E}$ is attenuated by GJBS. However, GJBS dose not affect the production of interferon- $\gamma$, interleukin (IL)-2, and IL-4 in MOLT-4 cells. These results indicate that GJBS has a potential regulatory effect on allergic reactions that are mediated by mast cells.
\end{abstract}

Keywords: gamijeonssibaekchulsan, histamine, passive cutaneous anaphylaxis, MOLT-4 cells

\section{INTRODUCTION}

Gamijeonssibaekchulsan (GJBS) is a typical Oriental medicine prescription which has been used in Korea for the treatment of allergic disease and the development of physical strength. To investigate how GJBS affects the anaphylactic reaction and immune function, we used murine models and $\mathrm{T}$ cell line (MOLT-4 cells).

In general, immediate-type hypersensitivity reactions that include urticaria, allergic rhinitis and asthma are mediated by various chemical mediators released from mast cells (Miescher \& Vogel, 2002). Histamine, one of the substances released on degranulation of mast cells, is a well character- ized and potent vasoactive mediator implicated in the acute phase of immediate-type hypersensitivity reactions (Moon et al., 2004; 2005). Compound $48 / 80$ is a well-known histamine releaser ( $\mathrm{Na}$ et al., 2004). Compound $48 / 80$ also induces ear swelling in a skin anaphylactic reaction model. Ear swelling is a predictive response of dermal sensitization (Kim \& Yang, 1999).

The secretory responses of mast cells can be induced by aggregation of their cell surface-specific receptors for immunoglobulin (Ig) E by the specific antigen (Metzger et al., 1986; Alber et al., 1991). The release of vasoactive substances is induced locally in naïve animals using $\operatorname{IgE}$. IgE is injected intradermally into naïve animals and the tested substance

Corresponding author: S.-H. Hong, College of Pharmacy, Wonkwang University, 344-2 Shinyong-dong, Iksan, Jeonbuk 570-749, Republic of Korea; tel: (82 63) 850 6805; fax: (82 63) 843 3421; e-mail: jooklim@wonkwang.ac.kr

Abbreviations: DNP, dinitrophenyl; FBS, fetal bovine serum; GJBS, gamijeonssibaekchulsan; HSA, human serum albumin; IL, interleukin; OPA, o-phthaldialdehyde; PCA, passive cutaneous anaphylaxis; RPMCs, rat peritoneal mast cells. 
mixed with a dye (typically Evans blue) is subsequently administered intravenously (usually after 24-72 h). Subsequent to the antigen-antibody reaction, vasoactive substances are released, resulting in a dramatic local increase in vascular permeability (Bazin et al., 1990). As the tested substance is mixed with a dye, the local cutaneous reaction is evidenced by a colored spot (Verdier et al., 1994). The skin of mouse is a useful site for studying passive cutaneous anaphylaxis (PCA) (Jeong et al., 2006).

Immunoregulatory cytokines play an important role in determining the nature and intensity of an immune response (Paul \& Seder, 1994; Abbas et al., 1996). Cytokines have been classified as Th1 types such as interleukin (IL)-2 and interferon (IFN)$\gamma$ or Th2 type IL-4, IL-5, IL-6 based on studies originally involving cloned murine $\mathrm{CD}^{+}{ }^{+} \mathrm{T}$ cell subsets (Mosmann et al., 1986; Mosmann \& Coffman, 1989). Th1 type cytokines promote cell-mediated immunity. Th2 cytokines primarily facilitate the development of humoral immune responses (Carter \& Dutton, 1996; Stephens et al., 2002). There are three classes of IFNs: interferon- $\alpha$ produced by leukocytes, interferon- $\beta$ produced by fibroblasts, and interferon- $\gamma$ produced by $\mathrm{T}$ cells. IFN- $\gamma$ induces both humoral and cellular immunological response.

We used murine models to investigate how GJBS affects the systemic anaphylactic reaction, ear swelling response, histamine release, and passive cutaneous anaphylaxis (PCA). Moreover, we investigated the effects of GJBS on cytokine production in MOLT-4 cells.

\section{MATERIALS AND METHODS}

Materials. We purchased compound 48/80, anti-dinitrophenyl (DNP) IgE, DNP-human serum albumin (HSA), metrizamide, o-phthaldialdehyde (OPA), Evans blue, avidin-peroxidase, and 2,2-azino-bis(3-ethylbenzthiazoline-6-sulfonic acid) (ABTS) from Sigma Chemical Co. (St. Louis, MO, USA). In addition, we purchased $\alpha$-minimal essential medium from Flow Laboratories (Irvine, UK); RPMI 1640, ampicillin, streptomycin, and fetal bovine serum (FBS) from Gibco BRL (Grand Island, NY, USA); anti-human IL-2, IL-4, and IFN- $\gamma$ antibodies, biotinylated anti-human IL-2, IL-4, and IFN- $\gamma$ antibodies, and recombinant (r) human IL-2, IL-4, and IFN- $\gamma$ from R\&D Systems (Minneapolis, MN, USA).

Animals. We purchased original stock of male ICR mice (4 weeks old) and male Wistar rats (7 weeks old) from Dae-Han Experimental Animal Center (Eumsung, Chungbuk, Republic of Korea) and maintained at the College of Pharmacy, Wonkwang University. The animals were housed three to five per cage in a laminar air-flow room maintained at a temperature of $22 \pm 1^{\circ} \mathrm{C}$ and relative humidity of $55 \pm 10 \%$ throughout the study. No animal was used more than once. The research was conducted in accordance with the internationally accepted principles for laboratory animal use and care as found in US guidelines (NIH publication \#85-23, revised in 1985).

Preparation of GJBS. GJBS extract which is a mixture of twenty five traditional drugs obtained from the Oriental Pharmacy, College of Oriental Pharmacy (Iksan, Republic of Korea). The ingredients of $120 \mathrm{~g}$ GJBS include $10 \mathrm{~g}$ of Astragali Radix (Astragalus membranaceus Bunge), $10 \mathrm{~g}$ of Taraxaci Herba (Taraxacum platycarpum $\mathrm{H}$. Dahlstedt), $10 \mathrm{~g}$ of Ulmi Cortex (Ulmus macrocarpa Hance), $6 \mathrm{~g}$ of Atractylodis Rhizoma Alba (Atractylodes japonica Koidzu$\mathrm{mi}), 6 \mathrm{~g}$ of Glycyrrhizae Radix (Glycyrrhiza uralensis Fischer), $6 \mathrm{~g}$ of Coicis Semen (Coix lacryma-jobi Linné var. ma-yuen Stapf), $6 \mathrm{~g}$ of Dioscoreae Rhizoma (Dioscorea batatas Decaisne), $5 \mathrm{~g}$ of Puerariae Radix (Pueraria lobata Ohwi), $4 \mathrm{~g}$ of Hoelen (Poria cocos Wolf), $4 \mathrm{~g}$ of Agastachis Herba (Agastache rugosa O. Kuntze), $4 \mathrm{~g}$ of Tricosanthis Radix (Trichosanthes kirilowi Maximowicz), $4 \mathrm{~g}$ of Magnoliae Flos (Magnolia denudata Desrousseaux), $4 \mathrm{~g}$ of Xanthii Fructus (Xanthium strumarium Linné), $4 \mathrm{~g}$ of Paeoniae Radix (Paeonia lactiflora Pallas), $4 \mathrm{~g}$ of Myristicae Semen (Myristica fragrans Houttuyn), $4 \mathrm{~g}$ of Mume Fructus (Prunus mume Siebold et Zuccarini), $4 \mathrm{~g}$ of Platycodi Radix (Platycodon grandiflorum A. De Candolle), $4 \mathrm{~g}$ of Citri Unshii Pericarpium (Citrus unshiu Markovich), $3 \mathrm{~g}$ of Ginseng Radix Alba (Panax ginseng C. A. Meyer), $3 \mathrm{~g}$ of Aucklandiae Radix (Aucklandia lappa Decne.), $3 \mathrm{~g}$ of Zanthoxyli Pericarpium (Zanthoxylum piperitum De Candolle), $3 \mathrm{~g}$ of Angelicae Gigantis Radix (Angelica gigas Nakai), $3 \mathrm{~g}$ of Ponciri Fructus (Poncirus trifoliata Rafinesqul), $3 \mathrm{~g}$ of Cimicifugae Rhizoma (Cimicifuga heracleifolia Komarov), $3 \mathrm{~g}$ of Bupleuri Radix (Bupleurum falcatum Linné). Extract of GJBS was prepared by decocting the dried prescription of herbs with boiling distilled water (GJBS/water=1:5, w/v). The extraction decocted for approx. $3 \mathrm{~h}$ was filtered, lyophilized, and kept a $4^{\circ} \mathrm{C}$. Dilutions were made in saline then filtered through $0.22-\mu \mathrm{m}$ syringe filter.

Compound 48/80-induced systemic anaphylactic reaction. Mice $(n=5)$ were given an intraperitoneal injection of the mast cell degranulator compound $48 / 80(8 \mathrm{mg} / \mathrm{kg})$. GJBS was dissolved in saline and administered orally with a sonde $1 \mathrm{~h}$ before the injection of compound 48/80. Mortality was monitored for $22 \mathrm{~min}$ after induction of anaphylactic reaction.

Ear swelling response. Compound 48/80 was freshly dissolved in saline and injected intradermally $(100 \mu \mathrm{g} / \mathrm{site})$ into the dorsal side of a mouse $(\mathrm{n}=5)$ ear using a microsyringe with a 28-gauge hypodermic needle. Ear thickness was measured with a 
digimatic micrometer (Mitutoyo, Japan) under mild anesthesia. Ear swelling response corresponded to an increase of thickness above baseline control values. Ear swelling response was determined $40 \mathrm{~min}$ after compound $48 / 80$ or vehicle injection. GJBS ( 0.01 to $1 \mathrm{~g} / \mathrm{kg}$ ) was administered orally $1 \mathrm{~h}$ before the compound 48/80-injection. The values obtained appear to represent the effect of compound 48/80 rather than the effect of vehicle injection (physical swelling), since the ear swelling response evoked by physiologic saline returned to almost baseline thickness within $40 \mathrm{~min}$.

Preparation of rat peritoneal mast cells (RPMCs). RPMCs were isolated as previously described (Jippo-Kanemoto et al., 1993). In brief, rats were anesthetized with ether, and injected with $20 \mathrm{ml}$ of Tyrode buffer B $(134 \mathrm{mM} \mathrm{NaCl}, 5 \mathrm{mM}$ glucose, $12 \mathrm{mM} \mathrm{NaHCO}{ }_{3}, 2.9 \mathrm{mM} \mathrm{KCl}, 0.34 \mathrm{mM}$ $\mathrm{NaH}_{2} \mathrm{PO}_{4}$ ) containing $0.1 \%$ gelatin (Sigma) into the peritoneal cavity; the abdomen was gently massaged for about $90 \mathrm{~s}$. The peritoneal cavity was carefully opened, and the fluid containing peritoneal cells was aspirated with a Pasteur pipette. Then the peritoneal cells were sedimented at $150 \times g$ for $10 \mathrm{~min}$ at room temperature and resuspended in Tyrode buffer B. Mast cells were separated from the major components of rat peritoneal cells (i.e., macrophages and small lymphocytes) according to the method described by Yurt et al. (1977). In brief, peritoneal cells suspended in $1 \mathrm{ml}$ of Tyrode buffer B were layered onto $2 \mathrm{ml}$ of 0.225 $\mathrm{g} / \mathrm{ml}$ metrizamide (density $1.120 \mathrm{~g} / \mathrm{ml}$; Sigma) and centrifuged at room temperature for $15 \mathrm{~min}$ at $400 \times \mathrm{g}$. The cells remaining at the buffer-metrizamide interface were aspirated and discarded; the cells in the pellet were washed and resuspended in $1 \mathrm{ml}$ of Tyrode buffer A containing calcium (10 $\mathrm{mM}$ Hepes, $130 \mathrm{mM} \mathrm{NaCl}, 5 \mathrm{mM} \mathrm{KCl}, 1.4 \mathrm{mM}$ $\mathrm{CaCl}_{2}, 1 \mathrm{mM} \mathrm{MgCl}$, $5.6 \mathrm{mM}$ glucose, $0.1 \%$ bovine serum albumin). Mast cell preparations were about $95 \%$ pure as assessed by toluidine blue staining. More than $97 \%$ of the cells were viable as judged by the Trypan blue uptake.

Histamine assay. Purified RPMCs were resuspended in Tyrode buffer A containing calcium for the treatment with compound 48/80. RPMC suspensions $\left(2 \times 10^{5}\right.$ cells $\left./ \mathrm{ml}\right)$ were preincubated for 10 min at $37^{\circ} \mathrm{C}$ before the addition of compound $48 / 80$ for stabilization. The cells were preincubated with GJBS (0.01 to $1 \mathrm{mg} / \mathrm{ml}$ ) for $30 \mathrm{~min}$, and then incubated for $20 \mathrm{~min}$ with compound 48/80 $(6 \mu \mathrm{g} / \mathrm{ml})$. The reaction was stopped by cooling the tubes in ice. The cells were separated from the released histamine by centrifugation at $400 \times g$ for $5 \mathrm{~min}$ at $4^{\circ} \mathrm{C}$. Residual histamine in the cells was released by disrupting the cells with perchloric acid and centrifugation at $400 \times \mathrm{g}$ for $5 \mathrm{~min}$ at $4^{\circ} \mathrm{C}$. The histamine content was measured by the OPA spectrofluorometric procedure of Shore et al. (1959). The fluorescent intensity was measured at $440 \mathrm{~nm}$ (excitation at $360 \mathrm{~nm}$ ) in a spectrofluorometer. The inhibition percentage of histamine release was calculated using the following equation:

$\%$ inhibition $=(A-B) \times 100 / A$

where A is histamine release without GJBS and B is the histamine release with GJBS.

PCA. IgE-dependent cutaneous reaction was generated by sensitizing the skin with an intradermal injection of anti-DNP IgE followed $48 \mathrm{~h}$ later with an injection of DNP-HSA into the mice tail vein. The DNP-HSA was diluted in phosphatebuffered saline (PBS). The mice were injected intradermally with $100 \mathrm{ng}$ of anti-DNP IgE into each of three dorsal skin sites that had been shaved 48 $\mathrm{h}$ earlier. The sites were outlined with a water-insoluble red marker. Forty-eight hours later, each mouse received an injection of $200 \mu \mathrm{l}$ of a 1:1 mixture of $1 \mathrm{mg} / \mathrm{ml}$ DNP-HSA in PBS and $4 \%$ Evans blue via the tail vein. One hour before this injection, GJBS was administered orally with a sonde. The mice were sacrificed $40 \mathrm{~min}$ after the intravenous challenge. The dorsal skin of the mouse was removed for measurement of the pigment area. The amount of dye was then determined colorimetrically after extraction with $0.5 \mathrm{ml}$ of $1 \mathrm{M} \mathrm{KOH}$ and $4.5 \mathrm{ml}$ of a mixture of acetone and phosphoric acid (in a ratio of 13:5, v/v), based on the method of Katayama et al. (1978). The absorbance of the extract was measured at $620 \mathrm{~nm}$ in a spectrophotometer, and the amount of dye was calculated using an Evans blue calibration curve.

MOLT-4 cell culture. T cell line MOLT-4 cells were grown in RPMI 1640 medium (Gibco BRL, USA) supplemented with 10\% FBS (JRH Bioscience, USA), $100 \mathrm{U} / \mathrm{ml}$ penicillin and $100 \mu \mathrm{g} / \mathrm{ml}$ streptomycin at $37^{\circ} \mathrm{C}$ in the presence of $5 \% \mathrm{CO}_{2}$.

Cytokines assay. The MOLT- 4 cells were treated with various concentrations of GJBS (0.01 to $1 \mathrm{mg} / \mathrm{ml}$ ) for $24 \mathrm{~h}$. We then used the enzymelinked immunosorbent assay (ELISA) method to assay the culture supernatants for the IFN- $\gamma$, IL-2, and IL-4 protein levels. To measure the cytokines, we used a modified ELISA method (Moon et al., 2007a). To measure the color development at 405 $\mathrm{nm}$, we used an automated microplate ELISA reader.

Statistical analysis. Our results are expressed as the mean \pm standard error of the mean (S.E.M.). The statistical evaluation of the results was performed by an independent $t$-test and an analysis of variance with a Tukey post hoc test. The results are significant with a value of $P<0.05$. 


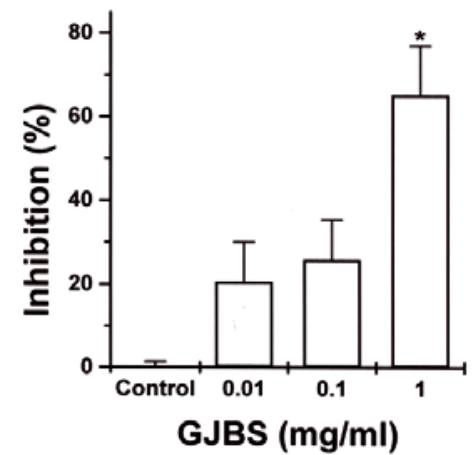

Figure 1. Effect of GJBS on compound 48/80-induced histamine release from RPMCs.

RPMCs $\left(2 \times 10^{5}\right.$ cells) were preincubated with various concentrations of GJBS at $37^{\circ} \mathrm{C}$ for $10 \mathrm{~min}$ prior to incubation with compound $48 / 80$. Results represent the mean \pm S.E.M. of three independent experiments. ${ }^{*} P<0.05$; significantly different from the control value.

\section{RESULTS}

Effect of GJBS on compound 48/80-induced systemic anaphylaxis

To assess the contribution of GJBS in anaphylactic reactions, we first used an in vivo model of systemic anaphylaxis. As a nonimmunologic stimulator, compound $48 / 80(8 \mathrm{mg} / \mathrm{kg})$ was used. After the injection of compound $48 / 80$, the mice were monitored for $22 \mathrm{~min}$, after which the mortality rate was determined. The period for observation of mortality was based on the control mice that had died in $22 \mathrm{~min}$ by compound $48 / 80$. As shown in Table 1, an oral administration of saline as a control resulted in a fatal reaction in $100 \%$ of each group. When GJBS was orally administered at the doses of 0.1 and $1 \mathrm{~g} / \mathrm{kg}$ $1 \mathrm{~h}$ before compound 48/80 injection, the mortality was significantly inhibited $(P<0.05$; Table 1$)$.

\section{Effect of GJBS on ear swelling response}

The fact that intradermal application of compound $48 / 80$ at 50 to $200 \mu \mathrm{g} / \mathrm{site}$ can induce an ear
Table 1. Effect of GJBS on compound 48/80-induced systemic anaphylactic reaction in mice.

\begin{tabular}{lccl}
\hline Treatment & $\begin{array}{l}\text { Dose } \\
(\mathrm{g} / \mathrm{kg})^{\mathrm{a}}\end{array}$ & $\begin{array}{l}\text { Compound 48/80 } \\
(8 \mathrm{mg} / \mathrm{kg})^{\mathrm{b}}\end{array}$ & $\begin{array}{l}\text { Mortality } \\
(\%)^{\mathrm{c}}\end{array}$ \\
\hline None (saline) & - & + & $100.0 \pm 0.0$ \\
GJBS & 0.01 & + & $40.0 \pm 10.0$ \\
& 0.1 & + & $20.0 \pm 5.0^{*}$ \\
& 1 & + & $20.0 \pm 5.0^{*}$ \\
& 1 & - & $0.0 \pm 0.0$ \\
\hline
\end{tabular}

${ }^{a}$ Groups $(n=5 /$ group $)$ of mice were orally pretreated with 200 $\mu \mathrm{l}$ of saline or GJBS. GJBS was given at various doses $1 \mathrm{~h}$ before

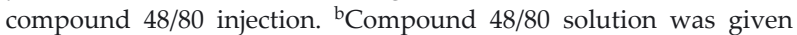
intraperitoneally to groups of mice. 'Mortality (\%) is presented as the 'number of dead mice $\times 100 /$ Total number of experimental mice'. Each value is the mean of three independent experiments. ${ }^{*} P<0.05$; significantly different from the control value.

swelling response in normal mice was confirmed in a previous experiment (Moon et al., 2007b). We chose a concentration of $100 \mu \mathrm{g} / \mathrm{site}$ for compound 48/80induced optimal ear swelling response in this experiment. As shown in Table 2, when mice were pretreated with GJBS for $1 \mathrm{~h}$, the ear swelling responses to compound 48/80 were significantly inhibited $(1 \mathrm{~g} / \mathrm{kg}$ GJBS; $P<0.05)$.

\section{Effect of GJBS on histamine release from RPMCs}

The inhibitory effect of GJBS on compound 48/80-induced histamine release from RPMCs is shown in Fig. 1. GJBS significantly inhibited compound 48/80-induced histamine release at the dose of $1 \mathrm{mg} /$ $\mathrm{ml}(P<0.05)$. The histamine fluorescence intensity at the doses of $0.01,0.1$, and $1 \mathrm{mg} / \mathrm{ml}$ was $26.82 \pm 3.34$, $24.92 \pm 3.38$, and $13.00 \pm 3.71$, respectively. Control and spontaneous values were $33.14 \pm 0.78$ and $1.69 \pm 0.59$.

\section{Effect of GJBS on PCA}

PCA is one of the most important in vivo models of anaphylaxis in local allergic reactions

Table 2. Effect of GJBS extract on compound 48/80-induced ear swelling response in mice.

The mice were orally administered with the indicated concentration of GJBS $1 \mathrm{~h}$ prior to the compound 48/80 application. Twenty microliters of compound 48/80 (100 $\mu \mathrm{g} / \mathrm{site})$ were injected intradermally. Results represent the mean \pm S.E.M. of three independent experiments. ${ }^{*} P<0.05$; significantly different from the control value.

\begin{tabular}{|c|c|c|c|c|}
\hline Treatment & $\begin{array}{l}\text { Dose } \\
(\mathrm{g} / \mathrm{kg})\end{array}$ & $\begin{array}{l}\text { Pre-thickness } \\
\qquad(\mathrm{mm})\end{array}$ & $\begin{array}{l}\text { Post-thickness } \\
(\mathrm{mm})\end{array}$ & $\begin{array}{c}\text { Inhibition } \\
(\%)\end{array}$ \\
\hline Control & - & $0.34 \pm 0.03$ & $0.74 \pm 0.01$ & $0.00 \pm 7.09$ \\
\hline \multirow[t]{3}{*}{ GJBS } & 0.01 & $0.30 \pm 0.00$ & $0.67 \pm 0.02$ & $9.45 \pm 5.90$ \\
\hline & 0.1 & $0.31 \pm 0.02$ & $0.63 \pm 0.01$ & $19.33 \pm 2.31$ \\
\hline & 1 & $0.32 \pm 0.02$ & $0.62 \pm 0.03$ & $26.83 \pm 2.14^{*}$ \\
\hline
\end{tabular}


(Wershil et al., 1987). Local injection of anti-DNP IgE followed by an intravenous antigenic challenge was performed. Anti-DNP IgE was injected into dorsal skin sites. After $48 \mathrm{~h}$, all animals were injected intravenously with DNP-HSA containing Evans blue dye. The cutaneous anaphylactic reaction was best visualized by the extravasation of the dye. When GJBS was orally administered to the mouse at the doses of 0.01 to $1 \mathrm{~g} / \mathrm{kg}$, the PCA was significantly and dosedependently inhibited $(P<0.05$; Fig. 2$)$. The maximal inhibition rate was $46.41 \pm 3.50$ at $1 \mathrm{~g} / \mathrm{kg}$ GJBS .

Effect of GJBS on the productions of IFN- $\gamma$, IL-2, and IL-4 in MOLT-4 cells

To assess the effect of GJBS on the production of cytokines, MOLT-4 cells were treated with various concentrations of GJBS for $24 \mathrm{~h}$. The levels of IFN- $\gamma$, IL-2, and IL-4 were analyzed by ELISA. As shown in Fig. 3, the effect of GJBS on the production of cytokines in MOLT-4 cells was not significant.

\section{DISCUSSION}

Stimulation of mast cells with compound $48 / 80$ is believed to initiate the activation of a signal transduction pathway which leads to histamine release. There have been some reports that compound $48 / 80$ is able to activate G proteins (Mousli et al., 1990a; 1990b). Chadi et al. (2000) announced that compound 48/80 activates mast cell phospholipase D (PLD) via heterotrimeric GTP-binding proteins. They observed that recombinant $G_{\beta 2 \gamma_{2}}$ subunit markedly synergized PLD activation by compound 48/80 in permeabilized RBL-2H3 cells. Murine mast cells are a good experimental model for the study on compound 48/80-induced histamine release (Alfonso et al., 2000). Tasaka et al. (1986) reported that compound $48 / 80$ increased the permeability of the lipid bilayer membrane by causing a perturbation of the membrane. That report indicates that the membrane permeability increase may be an essential trigger for the release of mediators from mast cells. We have shown that GJBS inhibits systemic anaphylactic reaction, ear swelling response, and histamine release (Tables 1 and 2, Fig. 1). Thus, it is possible to hypothesize that GJBS might act on the lipid bilayer membrane preventing the perturbation induced by compound 48/80.

The high-affinity IgE-receptor (FceRI) is expressed primarily by mast cells (Daeron, 1997). Cross-linking of IgE-bound FceRIs by a multivalent $\mathrm{Ag}$ on mast cells induces the release of biologically active mediators: the preformed mediators stored in the cytoplasmic granules, including histamine and $\beta$-hexosaminidase, and the newly synthesized me-

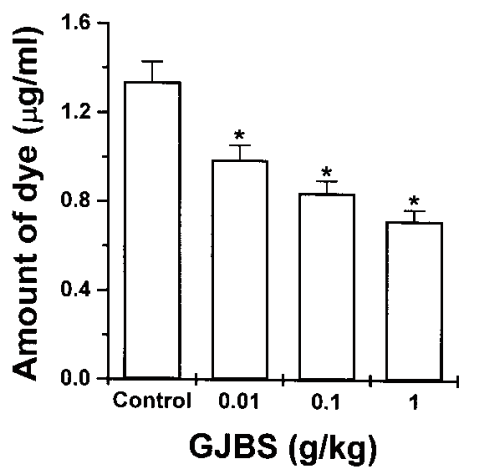

Figure 2. Effect of GJBS on $48 \mathrm{~h}$ PCA in mice.

GJBS was administered orally $1 \mathrm{~h}$ prior to the challenge with antigen (DNP-HSA). Results represent the mean \pm S.E.M. of three independent experiments ( $n=5 /$ group). ${ }^{*} P<0.05$; significantly different from the control value.

A

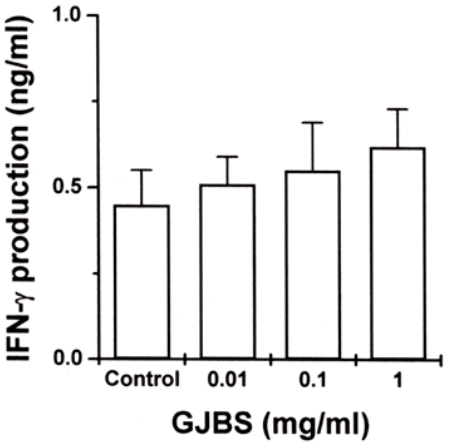

B

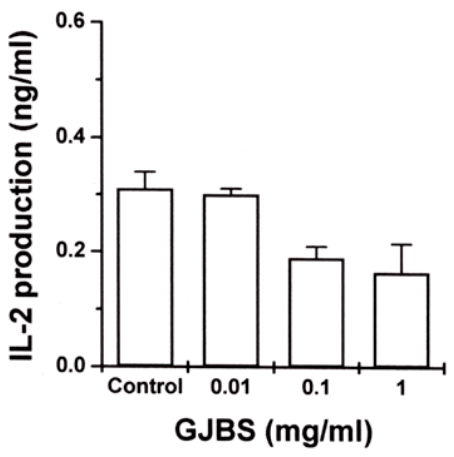

C

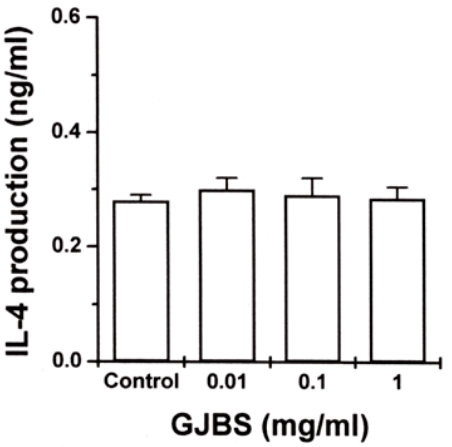

Figure 3. Effect of GJBS on IFN- $\gamma$, IL-2, and IL-4 production in MOLT-4 cells.

Culture supernatants were collected from saline- or GJBStreated MOLT- 4 cells cultured for $24 \mathrm{~h}$. Cytokine levels in culture supernatants were measured using ELISA. A. IFN$\gamma$ production; B. IL-2 production; C. IL-4 production. 
diators, such as leukotrienes and cytokines (Galli et al., 2005a; 2005b). To reproduce these reactions in animals, a PCA model was used in passively sensitized mice. Our results showed that GJBS dosedependently inhibits the PCA (Fig. 2). It is conceivable that GJBS inhibits the immediate type allergic reactions, probably through interference with the degranulation system.

Immunoregulatory cytokines play an important role in determining the nature and strength of an immune response (Paul \& Seder, 1994; Abbas et al., 1996). Recent studies indicate that the ratio of the two cytokine types, Th1 and Th2, is closely correlated with the outcome of many diseases, and controlling the Th1/Th2 ratio has been demonstrated as a therapeutic strategy for various diseases (Singh et al., 1999; Boothby et al., 2001; Spellberg \& Edwards, 2001). Many cancer vaccines, particularly in combination with immune adjuvants, elicit strong cellular immune responses, leading to the production of Th1-type cytokines, such as IFN- $\gamma$, IL-2, and TNF- $\alpha$ (Dalgleish, 2000). IFN- $\gamma$ is also an important cytokine in the host defense against infection by viral and microbial pathogens (Samuel, 2001). Previously, we reported that Th2 cytokine levels were higher than Th1 cytokine levels in various diseases, including cerebral infarction, allergies, and asthma (Kim et al., 2000; Jeong et al., 2002). Contrary to our expectation in this study, GJBS does not affect the production of IFN- $\gamma$, IL-2, and IL-4 in MOLT-4 cells (Fig. 3). We can therefore deduce that GJBS dose not affect the $\mathrm{T}$ cell-induced cytokines production but regulates the anaphylactic reactions by a direct effect on mast cells.

In conclusion, we have shown that GJBS can regulate the anaphylactic reactions that are mediated by mast cells. Overall, our results suggest that GJBS may have a clinical applicability to the allergic disorders.

\section{Acknowledgements}

This work was supported by the Ministry of Science and Technology (MoST)/Korea Science and Engineering Foundation (KOSEF) through the Vestibulocochlear Research Center (VCRC) at Wonkwang University (R13-2002-055-00000-0).

\section{REFERENCES}

Abbas AK, Murphy KM, Sher A (1996) Functional diversity of helper T lymphocytes. Nature 383: 787-793.

Alber G, Miller L, Jelsema C, Varin-Blank N, Metzger H (1991) Structure-function relationships in the mast cell high affinity receptor for IgE. Role of the cytoplasmic domains and of the beta subunit. J Biol Chem 266: 22613-22620.
Alfonso A, Cabado AG, Vieytes MR, Botana LM (2000) Functional compartments in rat mast cells for cAMP and calcium on histamine release. Cell Signal 12: 343350.

Bazin H, Barta O, Barta VD (1990) Hypersensibility de type I. In Immunologie animale (Pastoret P, Govaerts A, Bazin $\mathrm{H}$, eds) pp 313. Flammarion, Paris.

Boothby M, Mora AL, Aronica MA, Youn J, Sheller JR, Goenka S, Stephenson L (2001) IL-4 signaling, gene transcription regulation, and the control of effector $\mathrm{T}$ cells. Immunol Res 23: 179-191.

Carter LL, Dutton RW (1996) Type 1 and type 2: a fundamental dichotomy for all T-cell subsets. Curr Opin Immunol 8: 336-342.

Chadi A, Fraundorfer PF, Beaven MA (2000) Compound $48 / 80$ activates mast cell phospholipase D via heterotrimeric GTP-binding proteins. J Pharmacol Exp Ther 292: $122-130$.

Daeron M (1997) Fc receptor biology. Annu Rev Immunol 15: 203-234.

Dalgleish AG (2000) Cancer vaccines. Br J Cancer 82: 16191624.

Galli SJ, Kalesnikoff J, Grimbaldeston MA, Piliponsky AM, Williams CM, Tsai M (2005a) Mast cells as "tunable" effector and immunoregulatory cells: recent advances. Annu Rev Immunol 23: 749-786.

Galli SJ, Nakae S, Tsai M (2005b) Mast cells in the development of adaptive immune responses. Nat Immunol 6: 135-142.

Jeong HJ, Kim BS, Kim KS, Kim HM (2002) Regulatory effect of cytokine production in asthma patients by SOOJI CHIM (Koryo Hand Acupuncture Therapy). Immunopharmacol Immunotoxicol 24: 265-274.

Jeong HJ, Lee SA, Moon PD, Na HJ, Park RK, Um JY, Kim HM, Hong SH (2006) Alginic acid has anti-anaphylactic effects and inhibits inflammatory cytokine expression via suppression of nuclear factor-kappaB activation. Clin Exp Allergy 36: 785-794.

Jippo-Kanemoto T, Kasugai T, Yamatodani A, Ushio $\mathrm{H}$, Mochizuki T, Tohya K, Kimura M, Nishimura M, Kitamura Y (1993) Supernormal histamine release and normal cytotoxic activity of beige (Chediak-Higashi syndrome) rat mast cells with giant granules. Int Arch Allergy Immunol 100: 99-106.

Katayama S, Shionoya H, Ohtake S (1978) A new method for extraction of extravasated dye in the skin and the influence of fasting stress on passive cutaneous allergy in guinea pigs and rats. Microbiol Immunol 22: 89-101.

Kim HM, Yang DJ (1999) Effect of Kumhwang-san on anaphylactic reaction in a murine model. Immunopharmacol Immunotoxicol 21: 163-174.

Kim HM, Shin HY, Jeong HJ, An HJ, Kim NS, Chae HJ, Kim HR, Song HJ, Kim KY, Baek SH, Cho KH, Moon BS, Lee YM (2000) Reduced IL-2 but elevated IL-4, IL-6 and $\operatorname{IgE}$ serum levels in patients with cerebral infarction during the acute stage. J Mol Neurosci 14: 191-196.

Metzger H, Alcaraz G, Gogman R, Kinet JP, Pribluda V, Quarto R (1986) The receptor with high affinity for immunoglobulin E. Annu Rev Immunol 4: 419-470.

Miescher SM, Vogel M (2002) Molecular aspects of allergy. Mol Aspects Med 23: 413-462.

Moon PD, Choi IY, Na HJ, Jeong HJ, Kim CH, Kim HR, Kim YK, Park SK, Hong SH, Kim HM (2004) Rubus croceacanthus Leveille inhibits mast cell-mediated anaphylactic-like reaction and tumor necrosis factor- $\alpha$ secretion. Biol Pharm Bull 27: 1359-1363.

Moon PD, Na HJ, Jeong HJ, Hong SH, Kim SJ, Chae HJ, Kim HR, Choi JO, Lee SH, Shin JY, Kim HM (2005) Inhibitory effect of Gamibojungikgitang extract on 
mast cell-mediated allergic reaction in murine model. $J$ Pharm Pharm Sci 8: 94-101.

Moon PD, Lee BH, Jeong HJ, An HJ, Park SJ, Kim HR, Ko SG, Um JY, Hong SH, Kim HM (2007a) Use of scopoletin to inhibit the production of inflammatory cytokines through inhibition of the I $\kappa \mathrm{B} / \mathrm{NF}-\kappa \mathrm{B}$ signal cascade in the human mast cell line HMC-1. Eur J Pharmacol 555: 218-225.

Moon PD, Jeong HJ, Kim SJ, An HJ, Lee HJ, Yang WM, Park SK, Hong SH, Kim HM, Um JY (2007b) Use of electroacupuncture at ST36 to inhibit anaphylactic and inflammatory reaction in mice. Neuroimmunomodulation (in press).

Mosmann TR, Coffman RL (1989) TH1 and TH2 cells: Different patterns of lymphokine secretion lead to different functional properties. Annu Rev Immunol 7: 145-173.

Mosmann TR, Cherwinski H, Bond MW, Gieldin MA, Coffman RL (1986) Two types of murine helper T cell clone. I. Definition according to profiles of lymphokine activities and secreted proteins. J Immunol 136: 23482357.

Mousli MC, Bronner C, Bockaert J, Rouot B, Landry Y (1990a) Interaction of substance $P$, compound 48/80 and mastoparan with $\alpha$-subunit C-terminal of G protein. Immunol Lett 25: 355-358.

Mousli MC, Bronner C, Landry Y, Bockaert J, Rouot B (1990b) Direct activation of GTP-binding regulatory proteins ( $\mathrm{G}$ proteins) by substance $\mathrm{P}$ and compound 48/80. FEBS Lett 25: 260-262.

Na HJ, Moon PD, Hong SH, Shin JY, Kim HM (2004) Inhibitory effect of yunbutang on mast cell-dependent allergic reactions. Immunopharmacol Immunotoxicol 26: 233-242.
Paul WE, Seder RA (1994) Lymphocyte responses and cytokines. Cell 76: 241-251.

Samuel CE (2001) Antiviral actions of interferons. Clin Microbiol Rev 14: 778-809.

Shore PA, Burkhalter A, Cohn VH (1959) A method for fluorometric assay of histamine in tissues. J Pharmacol Exp Ther 127: 182-186.

Singh VK, Mehrotra S, Agarwal SS (1999) The paradigm of Th1 and Th2 cytokines: its relevance to autoimmunity and allergy. Immunol Res 20: 147-161.

Spellberg B, Edwards JE Jr (2001) Type 1/type 2 immunity in infectious diseases. Clin Infect Dis 32: 76-102.

Stephens R, Eisenbarth SC, Chaplin DD (2002) T helper type 1 cells in asthma: friend or foe? Curr Opin Allergy Clin Immunol 2: 31-37.

Tasaka K, Mio M, Okamoto M (1986) Intracellular calcium release induced by histamine releasers and its inhibition by some antiallergic drugs. Ann Allergy 56: 464469.

Verdier F, Chazal I, Descotes J (1994) Anaphylaxis models in the guinea-pig. Toxicology 93: 55-61.

Wershil BK, Mekori YA, Murakami T, Galli SJ (1987) ${ }^{125} \mathrm{I}-\mathrm{fi}-$ brin deposition in IgE-dependent immediate hypersensitivity reactions in mouse skin: demonstration of the role of mast cells using genetically mast cell-deficient mice locally reconstituted with cultured mast cells. J Immunol 139: 2605-2614.

Yurt RW, Leid RW, Austen KF (1977) Native heparin from rat peritoneal mast cells. J Biol Chem 252: 518-521. 